
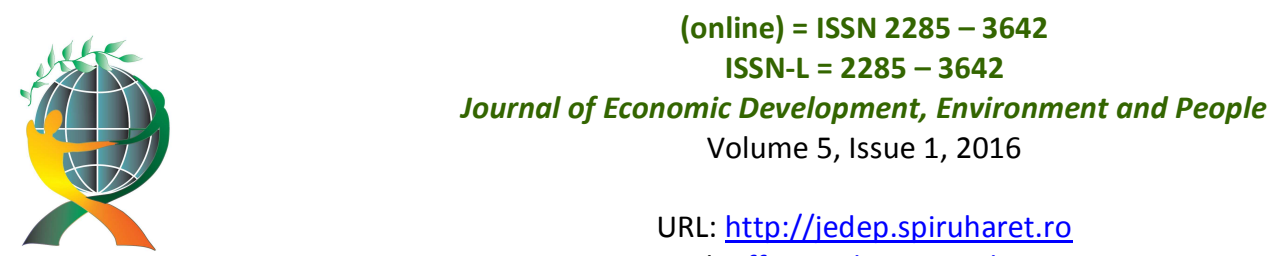

URL: http://iedep.spiruharet.ro

e-mail: office jedep@spiruharet.ro

\title{
New Trends in Economic Globalization
}

\author{
Elena Gurgu ${ }^{1,2}$ Aristide Cociuban ${ }^{1,2}$ \\ 1 "Spiru Haret" University, Ion Ghica, no. 13, Bucharest, 030045, Romania \\ ${ }^{2}$ Romanian Academy - National Institute of Economic Research "Costin C. Kiritescu"
}

\begin{abstract}
The long disputed and analyzed globalization has now become an objective phenomenon unprecedented in world history as magnitude and evolution. Criticized by some, revered by others, it seems that it follows its trajectory. For us, relevant are some negative aspects of globalization, but more significant are those that maintain balance and well-being of mankind. Based on the research conducted, we have concluded that both globalization and regionalization emerged and developed as a result of unprecedented increased competition in the level of trade of states or regions.
\end{abstract}

Keywords: globalization, regionalization, emerged and developed states or regions, competition, trade, internationalization.

JEL Codes: $F 10, F 23,010$

\section{Introduction}

Reducing barriers to international trade as a result of globalization, it has helped many countries to develop at a pace much faster than they otherwise could have. International trade contributes today significantly to the economic growth of a nation, and in turn the economic growth, influenced by exports, is the central component of the economic policy of a state that leads to improving the lives of millions of people, the development of each nation.

In this regard, we agree with the well-known opinion of the economist Joseph E. Stiglitz, which says that "those who criticize globalization too often ignore its benefits." This complex phenomenon has determined the decrease in intensity of the sense of isolation felt by many developing countries, through the more widely access to knowledge compared to previous centuries.

Tel: +40214551000, Fax: +40213143900

E-mail address: elenagurgu@yahoo.com

E-mail address: tedycociuban@yahoo.com 


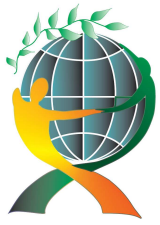

\author{
(online) $=$ ISSN $2285-3642$ \\ ISSN-L = $2285-3642$ \\ Journal of Economic Development, Environment and People \\ Volume 5, Issue 1, 2016 \\ URL: $\underline{\text { http://iedep.spiruharet.ro }}$ \\ e-mail: office jedep@spiruharet.ro
}

We believe that assessing whether globalization is good or bad involves objectively identifying arguments that support the one or the other. Some authors consider, and we support this view, that any negative side of globalization has, in its turn, a good part. For example, liberalization of markets in developing countries, even if the activity has affected domestic producers, has brought great benefits to poor consumers, who could buy goods at lower prices and higher volume. Examples of this are many and eloquent.

Proponents of globalization deemed that this phenomenon always mean progress. For many other authors, the widening disparities between the rich and the poor are much more profound than the benefits of globalization, reason for which it is considered "an attack on democracy and welfare." The critics of globalization accuse the West of hypocrisy and somehow we think that they are right; they forced poor countries to eliminate most trade barriers, but they continued in most cases to apply them. In these circumstances, countries with lower levels of development have been unable to export surplus of their agricultural production - often the only economic activity - and to reduce the trade deficit and payments. Moreover, when setting the priorities of globalization, it has been found that poor countries have a much lower benefit compared with major global players.

\title{
2. Globalization's effects
}

According to those studied in the economic literature, it appears that the effects of globalization are different in proportion and destination, and tackling it often generates differences of opinion and sometimes conflicts. We may mention here, world or regional movements that comprise important mass anti-globalization protesters to address its effects. We drew the conclusion that these protests are all a result of globalization, because the communication to fix the date and place of the demonstrations, the international transport, the organized conferences, etc., all used exclusively the instruments of globalization.

In one of his speeches, Butros Butros-Ghali, former UN General Secretary, stated that "we live in the middle of a world revolution... Our planet is under huge pressure of two opposing forces: globalization and disintegration". (Butros Butros-Ghali: 2006) The major concern that appears worldwide is due to the fact that the world population is in a continuous rise while natural resources, many of them non-renewable, tend to be approaching a critical point. We believe that such problems should find a solution in globalization.

Deeply marked by the economic situation that is difficult for most of its inhabitants, the same Butros Butros-Ghali added: "History shows that those who are in the midst of revolutionary changes rarely understand the ultimate meaning of this", referring to the powers that often promote personal interests and then those of the group. (Butros Butros-Ghali: 2006)

In our view, globalization is primarily a political act which establishes the "rules of the game". This is why the most powerful wins and sometimes takes it all. Economic, demographic and cultural strength are also important, but positioning the criteria of a nation in the global system is largely political. 


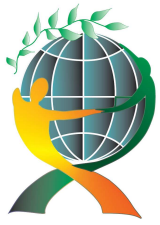

\author{
(online) $=$ ISSN $2285-3642$ \\ ISSN-L = $2285-3642$ \\ Journal of Economic Development, Environment and People \\ Volume 5, Issue 1, 2016 \\ URL: $\underline{\text { http://iedep.spiruharet.ro }}$ \\ e-mail: office jedep@spiruharet.ro
}

Currently, all earthly universes are comprised of a true "revolution"; no one is "spared" the transformation of this. Since ancient times, the law of natural selection separated the world into two segments: one of the few and mighty, asserting itself in any way and at any price, and another of the many who want but do not have sufficient means to dominate. We believe that the world economy is governed by the same law. There are many who try to reach the top of the hierarchy, but few succeed. Apparently, most often, the new conquests of science and technology divide the rich and poor in losers and winners, strong and weak depending on their possibilities of access to them.

Understood as an unleashing of market forces and depriving the state of the global economic power, according to some analysts, globalization is a process imposed by force for most nations, which cannot evade it.

It is an acknowledged fact that globalization generates different effects at the level of states. In general, major economic powers are defining and coordinating universal principles of this process. We believe that for the United States, globalization has been a process in motion and supported by their own political and economic elite. The only superpower remaining intact is the last nation that has maintained an important degree of national sovereignty. Just by its economic strength, the US became the last existing order in the chaos factor, that of global interdependence.

According to some analysts, the world should look like an organized global governance to stimulate the economic competition between the three great powers: America, centred on the United States, United Europe, centred on Berlin-Moscow axis, and Asia-Oceania, in which China counterbalances the economic growth coming from Japan. These three super-regions should be represented by a single forum.

\title{
3. New economic order
}

From the above is clear that globalization has not just one perception, nor it may take the form of a single representation of the interests of any single country. The new economic order demanded by globalization, which asserts itself with an impetuous force, encounters many shortcomings, including perceptions. Interesting to note is the fact that the "periphery" always acts differently than the centre and this could have significant effects in reshaping the world.

It became obvious to everyone that the great powers have an important word, say for example in the policy development world, only that in this process, all the states have engaged. We could easily see that the grievances of the poor but many are increasingly felt. Continuing their marginalization could lead to a conflict whose solution will generate big losses worldwide.

Anti-globalization movements are a response to the attitude of some international organizations WTO, for example - that not a few times, though the policy promoted, disfavoured even more the underdeveloped economies and continued to benefit the great powers. "Too rich and too poor" is a slogan whose meaning is not to be explained.

The primary task extremely difficult of the globalization process is, in our view, reducing the gaps between the rich and the many poor. The identification of viable solutions and adopting practical measures is a lengthy process, involving some huge efforts. The silence of the world will depend largely on the 


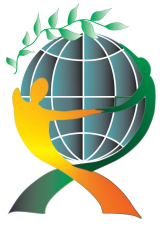

\author{
(online) $=$ ISSN $2285-3642$ \\ ISSN-L = $2285-3642$ \\ Journal of Economic Development, Environment and People \\ Volume 5, Issue 1, 2016 \\ URL: $\underline{\text { http://iedep.spiruharet.ro }}$ \\ e-mail: office jedep@spiruharet.ro
}

success of this venture. More than ever, we need consensus in adopting development policies for the world. Only through joint action we will be able to find a fair solution to the major problems of the planet. In fact, ideational unit is not a bad thing if it converges toward general welfare and freedom of action.

\title{
4. The optimal way of solving the mankind problems
}

According the research made so far, we consider that globalization can be an optimal way of solving the serious problems facing humanity today. But the favourable effects of this process will be seen and felt by all states equally? Some authors believe that the winners will take it all, meaning that major economic powers will record unprecedented gains, while most states will endure the increasingly difficult burden of poverty. Optimistic analysts, with whom we agree, believes that globalization, by its nature, will improve the economic and social situation of individual countries, but the proportion of benefits will not be the same for all, as well as any economic, financial or scientific contribution and social participation in the achievement of this process will not be equal. We would like to believe that, ultimately, all states will have a piece of the "pie" in particular, but the slices will most certainly be uneven. The category of pessimistic analysts supports the opposite, that the gap between rich and poor will widen increasingly more without chance of recovery. Venturing to make such statements it's a little exaggerated, however. The truth will be reflected when the future becomes the present, meaning that this process must be monitored in time with its qualities and drawbacks. It should be undertaken with caution in order to limit the negative impact of the influence factors.

The globalization of the world economy, in our opinion - as that of other authors too - can be understood as a spatial phenomenon, with two extremes: at one side, local communities with their specific problems, and at the other - the global society which we are all striving together for.

Today globalization is almost a euphemism, sometimes having the exactly opposite meanings of those which it suggests; it can mean different things in different contexts. Economic globalization has become noticeable once the industrial enterprises began their abroad expansion.

In one of his works, which has made a special contribution to the launch of "globalization", the American economist Michael E. Porter - which we fully agree with - repeatedly refers to the fact that, currently, we can speak of the existence of global industries "where the competitive position of a company in a particular country is affected in a significant manner by the strategy adopted by other companies in other countries". (Michael E. Porter: 2006) The meaning of the concept of global industry began to be translated "to produce cargo anywhere, using resources from anywhere, to locate the company sells everywhere and everywhere"; it changes constantly, depending on trends and developments in the economic world.

Globalization can be seen as a positive phenomenon, the only chance to increase welfare or, conversely, as the sole responsible for the complex issues facing the planet in recent years. In their reference work "The globalization trap", authors Hans-Peter Martin and Harald Schumann claimed that "relocation of production, simplification, reduction of prices, layoffs, high performance economy based on high-tech kidnap the work of consumption society and throw on the street own consumers". They warn that 


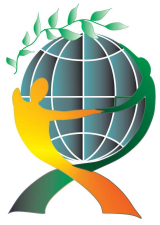

\author{
(online) $=$ ISSN $2285-3642$ \\ ISSN-L = $2285-3642$ \\ Journal of Economic Development, Environment and People \\ Volume 5, Issue 1, 2016 \\ URL: http://iedep.spiruharet.ro \\ e-mail: office jedep@spiruharet.ro
}

"...an economic and social earthquake of dimensions unknown before is announced". (Martin Hans-Peter, Schuman Harald: 1999) The entire work is very well documented and the authors are knowledgeable in the field, drawing together many studies and reports on the global interdependence of the economy, the environment and politics. The aim of their work is to warn mankind that any phenomenon of ample dimensions should be viewed and analyzed in its complexity, taking into account not only the positive aspects generated by the interaction, but also risks, sometimes huge, which could mitigate or even reverse the effects expected if it is not viewed with caution. These ideas are supported by many other authors, without minimizing the positive effects of globalization proposed to keep under control the economy and joint action to identify ways to maximize long-term performance, worldwide.

As for us, we believe that global economic globalization leads to increased competence, effectiveness nation-wide economic activity, but also reduce social protection to employees. Whether it's about building cars or computers, chemistry, electronics, telecommunications or postal services, retail trade and finance, in any place in the world where products or services are negotiated freely without even considering any border, employees get into a seemingly unstoppable whirlpool in order to assess their value. In recent years, in OECD countries, the number of better paid jobs has reduced considerably. If, in the not too distant past, businesses were independent, belonging to a single country, gradually, the biggest of all began to locate branches and subsidiaries in other countries and areas, where they hoped to obtain significant profits by using cheaper local resources. The benefit was even for the host country because the created units were absorbing some of the local workforce and the products made there were to be sold by the parent company, thus stimulating international trade flows and employment in this area.

\title{
5. The delocalization phenomenon
}

Relocation subsequently led to unprecedented growth of global production. Transnational corporations do not belong anymore to a single nation. For example, the relocation of the Coca-Cola business, a global image of refreshments, increased significantly the production, without registering as well sustained rhythms in the international trade. The mentioned company's management appreciated that it is more efficiently to create production centres in the consuming country than to export the finished product, as it was happening in the past, when the distribution prices increased significantly due to the transport costs. The same trends, of branches location in other countries, are available for corporations in all industries.

Also, from studies researched and done we noticed that outsourcing production recorded significant successes in previous years. Foreign companies resorted to production relocation (internationalization) to reduce production costs, particularly through the use of cheap labour coming from developing countries. Lately, it seems that this type of activity is limited in scope. A study on the clothing production under loan contract shows that since 2003 this type of activity no longer is interesting because, with the liberalization of trade in these product categories, China - the largest producer, won the major share of the market segment concerned by very low production costs, due to the low cost of labour. Waiver of this form of production was reflected negatively on developing countries, by significantly reducing employment. The only solution for the future was found in creating own profile enterprises that use local labour force, well- 


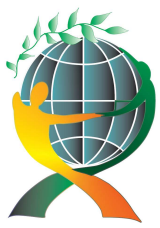

\author{
(online) $=$ ISSN $2285-3642$ \\ ISSN-L = $2285-3642$ \\ Journal of Economic Development, Environment and People \\ Volume 5, Issue 1, 2016 \\ URL: $\underline{\text { http://iedep.spiruharet.ro }}$ \\ e-mail: office jedep@spiruharet.ro
}

qualified. To ensure competitiveness, production costs of national goods must not exceed world prices. Moreover, the struggle for employment and keeping a market segment is fierce.

Neither the high tech situation is optimistic for the workforce, only that here is affected the advanced countries' population. In the software industry, for example, companies that once used the prestige of skilled labour in developed countries now turns to specialists from developing countries to reduce wage costs and therefore unit costs of production. Since the eighties of the last century design department heads from companies such as Motorola, IBM, Hewlett-Packard etc. prefer to hire specialists from India, for payment of lower wages, which compete well with the qualifications of the developed countries.

The studies and research show that if until a few years ago, the mentioned companies operated in the advanced countries and resorted to labour from outside (migration is high), now there is an expansion of the companies mentioned and many others, such as Digital Equipment, Siemens-Nixdorf, Deutsche Bank etc. in underdeveloped countries, but with manpower training. The reason of some branches location in India, Taiwan, Singapore etc. is always the same: employees of these states have received exceptional skills in English language from local universities and they cost the company only a tiny part of the wages received by a "colleague" in Europe or the US. "With the price of a Swiss we can engage three Indians", appreciates Hannes Krummer, spokesman for Swissair. (Martin Hans-Peter, Schuman Harald: 1999) Since 1990, over a million skilled programmers made their way on the computer market, coming from Russia and Eastern Europe, the cost of which seems to be more convenient. Moreover, even these less demanding professionals are faced with cheaper competition: the computer itself proves unbeatable. With the help of the new IT tools, it is estimated that the future programmer will perform operations that are currently produced by 100 of his colleagues; a very pessimistic forecast for the elite front progress. Karl Schmitz from Technology Consulting and Systems Company considers that work under loan contract in the processing sector is a "temporary phenomenon" and has predicted that out of the 200,000 jobs in the German software industry will remain only 2,000.

According to the research we have conducted in various other fields, it appears that the same trend is recorded in all advanced countries and in sectors such as banking, stock exchange, telephony, where the activity will take place only online. Regarding the financial sector, Ulrich Cartellieri, Board Member at Deutsche Bank, with whom we agree with, says that "banks are now what was in the 90s the steel industry" (Edmondson, Gail: 2004). In a study on the plans of the top 50 banks in the world, it is expected that even in the banking branch, in the next 10 years, half of the employees will lose their jobs.

\title{
6. The future of globalization
}

But how will the globalization of the economy look like in the future? We find the answer in a supplement of the British weekly "The Economist", where Brian Beedham endeavoured to answer the difficult question: "How will the world look like in 2050s?". (Brian Beedham: 1999) It will be, first, a world free from the scourge of the two great "isms" of the twentieth century: fascism and communism. Another "ism", ideological authoritarianism, "will be put in the corner", and any important country will not try the unfortunate experiment of the state monopoly over the economy. In a way or another, everyone will 


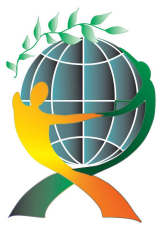

\author{
(online) $=$ ISSN $2285-3642$ \\ ISSN-L = $2285-3642$ \\ Journal of Economic Development, Environment and People \\ Volume 5, Issue 1, 2016 \\ URL: $\underline{\text { http://iedep.spiruharet.ro }}$ \\ e-mail: office jedep@spiruharet.ro
}

embrace market capitalism. And new technologies will simplify the movement of capital and ideas so that governments will find difficult to exercise strict control over these processes.

Obviously, in our opinion, sooner or later, all states, except for a few from Africa and Asia that are haunted by chaos, will direct the savings towards competitive capitalism. "In Central and Western Europe, the new states that will be born will be more attracted to take economic decisions through collective action. What could result, ultimately, even in a kind of economic and political union".

But as we said earlier, the way through the "postmodern state" will be covered with different speeds in different countries. "It will take decades until the world reaches a certain economic and political uniformity", believes the American political scientist, former official of the US Department of State, Francis Fukuyama, who recommend us that "in the first half of the $21^{\text {st }}$ century we must learn to have patience". (Francis Fukuyama: 1992) And this especially because the road ahead is full of unknowns. But could the states disappear or diminish their authority under the pressure of the technological revolution and because of a course towards the free democracy of the universal market?

In some respects, the role of states will diminish, possibly substantially, but their task is far from complete. First of all, because the 'open world' does not affect the main power exercised by the state's own borders - the citizens' taxation and how they spend their money. In the richest countries, the percentage of GDP spent by the state has increased since 1980 . Through its monetary and fiscal policies, the state has the means necessary to achieve its objectives, regardless of the spectacular cross-border movement of capital. Secondly, it is too early to consider the disappearance of the state as an institution, because so far there are no signs that it might be replaced with something else. From this point of view, we consider that neither the UN nor the multinationals cannot substitute states, and the pioneering of the European Union, at least for the foreseeable future, is a singular experience.

But whatever happens in the future, the world of 2050s will have to look like one big family, made up of countries that have no serious grounds for dispute. We believe that over the next 50 years the world will not look so different from the one nowadays that it will no longer be recognized. On the stage of the world will act more powers, one of which (the US) has some advantage over the others, but we cannot know how it will maintain this advantage nor which of its main competitors will be detached from the bunch in the race for Planetary supremacy.

Power relationships of the future depend mainly on two factors. The first factor: if the current partnership between the US and Europe will be maintained through a common defence (in a redefined NATO or a possible alliance for democracy) or if the Alliance will break. In this case, America will approach Japan, but will become weaker and Europe will be "nearly paralyzed". The second factor: who will be the "challenger" of America and of the world's main powers?

For the moment, we think that China has a good chance, whose gross national product would be equal in 2020 with that of America and will be twice as large as Russia's. But "a stronger China might not be a warrior China?" In any case, China will not be more than US in the nineteenth century. 


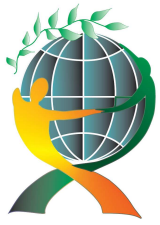

\author{
(online) $=$ ISSN $2285-3642$ \\ ISSN-L = $2285-3642$ \\ Journal of Economic Development, Environment and People \\ Volume 5, Issue 1, 2016 \\ URL: http://iedep.spiruharet.ro \\ e-mail: office jedep@spiruharet.ro
}

We think that Russia of the 2020s, economically surpassed by China and preoccupied with rebuilding its military force, will be focused on the vulnerability of its eastern territories, which could lead to a NATO approach. Just as it might stay away from the Atlantic Alliance, remaining in the Slav area, trying to recover Ukraine and pursue its special interests in the Baltic Sea and the Balkans.

Zbigniew Brzezinski, former American presidential adviser on security issues, in his 1997's book, The Grand Chessboard, said that "the big planetary games that will lead the world in economic terms will be made in Eurasia" (and not in Africa, America or South Pacific), between four, five or six powers, which will compete or will perform in different variants. The "soft spot" of the great Eurasian chessboard will be, according to Brzezinski, Central Asia, with its reserves of oil and gas still unrated. (Zbigniew Brzezinski: 2005)

And to conclude optimistically, the author who ventured to outline the global landscape of 2050s, Francis Fukuyama, said at one point, in an encouraging manner: "Welcome to an exciting $21^{\text {st }}$ century!" (Francis Fukuyama: 1992) Robert Reich, in an article published in the "World Almanac and Book of Facts 2000 - The World Atlantis 2000", believes that "all we can do at the beginning of the new century and millennium is hope that the process of seeking a balance is maintained as far as possible with respect to humanity". (Robert Famighetti: 2000)

\title{
7. Conclusions
}

In conclusion, globalization increases the performance and efficiency of businesses by optimizing the use of resource and maximizing the results, but the consequences of progress, though laudable in terms of scientific research, appear to be very tough in the social plan. We believe that the decline in employment in traditional sectors would not be so great if new profession were created in parallel, in which the redundant labour force would be turned off. Private entrepreneurs are interested in permanent cost reductions, not in social problems. International bodies and organizations argue that unemployment can be maintained within acceptable limits, because the tertiary sector will still be generating offers and new jobs.

Will globalization solve all these problems that we face today? We believe that the role of globalization is to take action and find solutions for environmental protection in the long term. Solutions must be found, especially by specialized international bodies and organizations that are governing the global economic phenomenon. A comprehensive law is more effective than a limitation or a local law.

In this entire context of globalization, it would be necessary to take into account an economic development that does not affect the environment, and it is a question of developing the concept of ecobio-economic development or sustainable development. Programs developed for a sustainable development are numerous, but they must by applied and have a purpose. The aphorism "Think globally and act locally" is a reality that must take into account all states, regardless of their level of development. As a recommendation, accepted by everyone, but from an operational perspective, there are still many deficiencies to be solved.

\section{References:}




\author{
(online) $=$ ISSN $2285-3642$ \\ ISSN-L = 2285 - 3642 \\ Journal of Economic Development, Environment and People \\ Volume 5, Issue 1, 2016 \\ URL: http://iedep.spiruharet.ro \\ e-mail: office jedep@spiruharet.ro
}

[1] Bari, I. (2005), Globalizarea economiei, Editura Economică, Bucureşti

[2] Bari, I. (2010), Tratat de economie politică globală, Editura Economică, Bucureşti

[3] Baumann, Z. (2009), Globalizarea şi efectele ei sociale, Editura Antet, Bucureşti

[4] Baumil, W.J. ( 2009), Capitalismul bun, capitalismul rău, Editura Polirom, Bucureşti

[5] Bonciu, F. (2009), Investițiile străine directe şi noua ordine economică mondială, Editura Universitară, Bucureşti

[6] Boutros-Ghali, Boutros (2006), The world is his oyster, Weekly Ahram, 18 January 2006.

[7] Brown, L. R. (2011), Lumea pe marginea prăpastiei, Editura Tehnică, Bucureşti

[8] Brown, L. R. (2011), Planul B 4.0 - Mobilizarea generală pentru salvarea civilizației, Editura Expert, Bucureşti

[9] Brzezinski, Z. (2005), Marea Dilemă: a domina sau a conduce, Editura Scripta, Bucureşti

[10] Buffett, W. (2010), Criza economică şi profeții ei, Editura Litera, Bucureşti

[11] Beedham, Brian (1999), Who are we, who are they?, The Economist, New York, 29 July 1999

[12] Buzan, C. G. (2011), Paradisurile fiscale şi centrele financiare offshore, Editura C.H. Beck, Bucureşti

[13] Canton, J. (2010), Provocările viitorului: Principalele tendințe care vor reconfigura lumea în următorii 5, 10, 20 de ani, Editura Polirom, Iaşi

[14] Castleden, R. (2011), Conflicte care au schimbat lumea, Editura Meteor Press, Bucureşti

[15] Dinu, M. (2004), Globalizarea şi aproximările ei, Editura Economică, Bucureşti

[16] Dobrescu, E. (2010), Cartea crizelor. O privire optimistă, Editura Woltares Kluwer, București

[17] Edmondson, Gail (2004), "Has Deutsche Bank Lost Its Way?; Having failed to find a merger partner, Ackermann plans a radical makeover. Investors are sceptical", Business Week, The McGraw-Hill Companies

[18] European Commission - Forward Studies Unit (2010), Scenarios: Europe in 2010. One Europe, five destinies, Institute of World Economy Publisher, Bucharest

[18'] Famighetti, R. (2000), World Almanac and Book of Facts 2000, a Robert Reich essay, St Martin's Press, New York

[19] Farndou, J. (2008), Secretele Chinei. Ascensiunea unei noi superputeri mondiale, Editura Litera International, Bucureşti

[20] Friedman, T. L. (2006), Lexus şi măslinul, Editura Polirom, Iaşi

[21] Friedman, T. L. (2010), Cald, plat şi aglomerat, Editura Polirom, Bucureşti

[22] Friedman, T. L. (2006), Pământul este plat. Scurtă istorie a secolului XXI, Editura Polirom, Iaşi

[22'] Fukuyama, F. (1992), The End of History and the Last Man, Free Press Publishing House, New York 


\author{
(online) $=$ ISSN $2285-3642$ \\ ISSN-L = $2285-3642$ \\ Journal of Economic Development, Environment and People \\ Volume 5, Issue 1, 2016 \\ URL: http://iedep.spiruharet.ro \\ e-mail: office jedep@spiruharet.ro
}

[23] Ghiță, M. (2009), Guvernanța corporativă, Editura Economică, Bucureşti

[24] Gilpin, R. (2007), Economia mondială în secolul XXI. Provocarea capitalismului global, Editura Polirom, Iaşi

[25] Greenspan, A. (2008), Era turbulențelor. Aventuri într-o lume nouă, Editura Publică, Bucureşti

[26] Gurgu, E. (2011), Economie internațională. Relații economice internaționale, Editura Fundației România de Mâine, Bucureşti

[27] Gurgu, E. (2011), Globalizarea activității economice. Realități și tendințe, Editura Fundației România de Mâine, București

[28] Gurgu, E. (2011), Economie mondială, Editura Fundației România de Mâine, Bucureşti

[29] Held, D., Mc Grew, A., Goldblatt, D., Perraton, J. (2007), Transformări globale. Politică, economie, cultură, Editura Polirom, Bucureşti

[30] Hevitt, S. D., Dubner, S. J. (2010), Superfreakonomics, Editura Publică, Bucureşti

[31] Ivan, A. (2009), Sub zodia Statelor Unite ale Americii - de la Ideea europeană la Comunitățile Economice Europene, Editura CA Publishing

[32] Korten, C. D. (2009), Proiectul noii economii, Editura Antet, Bucureşti

[33] Martin, Hans-Peter, Schuman, Harald (1999), Capcana globalizării. Atac la democrație și bunăstare, Editura Economica, București

[34] Maynard, K.J. (2009), Teoria generală a ocupării forței de muncă, a dobânzii şi a banilor, Editura Publică, Bucureşti

[35] Naisbits, J. (2004), Global paradox, Brealey Publishing House, London

[36] Porter, M. E. (2006), Competition in Global Industries, Boston, Mass., Harvard Business School Press

[37] Postelnicu, Gh., Postelnicu, C. (2008), Globalizarea economiei, Editura Economică, Bucureşti

[38] Roberts, P. (2008), Sfârşitul petrolului, Editura Litera Internațional, Bucureşti

[39] Ronbini, N., Mihm, S. (2010), Economia crizelor - Curs fulger despre viitorul finanțelor, Editura Publica, Bucureşti

[40] Ruthkopf, D. (2009), Superclass - Elita globală a puterii şi lumea sa, Editura Publica, Bucureşti

[41] Schumpeter, J. A. (2011), Poate supraviețui capitalismul? Distrugerea creatoare şi viitorul economiei globale, Editura Publica, Bucureşti

[42] Sen, A. (2004), Dezvoltarea ca libertate, Editura Economică, Bucureşti

[43] Shenkar, O. (2011), Secolul chinezesc, Editura Teora, Bucureşti

[44] Smick, D. M. (2009), Lumea e rotundă. Pericolele ascunse pentru economia globală, Editura Publică, Bucureşti 


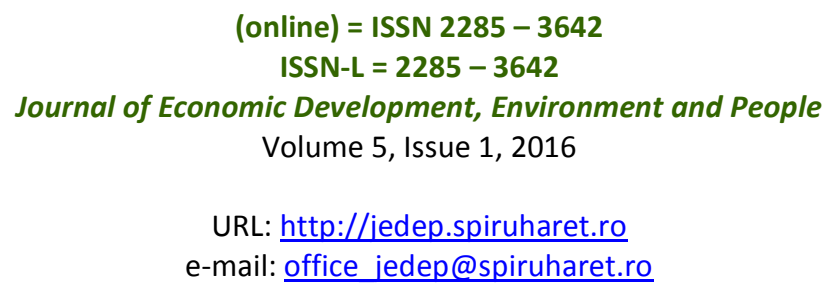

[45] Smith, A. (2010), Avuția națiunilor, Editura All, Bucureşti

[46] Stiglitz, J. E. (2003), Globalizarea. Speranțe şi deziluzii, Editura Economică, Bucureşti

[47] Stiglitz, J. E. (2008), Mecanismele globalizării, Editura Polirom, laşi

[48] Stiglitz, J. E. (2010), în cădere liberă: America, piața liberă şi prăbuşirea economiei mondiale, Editura Publică, Bucureşti

[49] Taleb, N. N. (2010), Lebăda neagră, Editura Curtea Veche, Bucureşti

[50] Toffler, A., Toffler, H. (2006), Avuție în mişcare, Editura Antet, Bucureşti 